\title{
Effects of Soy Protein and Isoflavones Intake on HDL Metabolism in Asian Populations
}

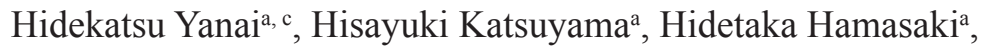 \\ Shinichi Abe ${ }^{\mathrm{b}}$, Norio Tada ${ }^{\mathrm{b}}$, Akahito Sako ${ }^{\mathrm{a}}$
}

\begin{abstract}
High-density lipoprotein (HDL) has been shown to have a variety of functions that contribute to anti-atherogenesis. Therefore, low HDL-cholesterol (HDL-C) level is significantly associated with the development of coronary artery diseases (CADs). Soy and isoflavones have been proposed to reduce the risk of CAD. However, the underlying mechanisms for soy and isoflavone-induced reduction of coronary risks remain largely unknown. To understand effects of lifestyle on lipids metabolism, the existence of interracial differences should be considered. Here we reviewed published articles about effects of soy and isoflavone intake on HDL metabolism. We regarded systematic review and meta-analysis and also clinical studies which were performed in Asian populations as important articles in this review. Evidences obtained from clinical trials performed in Asian populations showed that effects of soy protein and isoflavones on HDL-C were limited, which may be due to limited studied population such as postmenopausal women. Meta-analyses indicated that intake of soy protein and isoflavones is beneficially associated with HDL metabolism.
\end{abstract}

Keywords: Atherosclerosis; High-density lipoprotein; Isoflavones; Meta-analysis; Soy protein

\section{Introduction}

High-density lipoprotein (HDL) has been shown to have a variety of functions that contribute to anti-atherogenesis: reverse cholesterol transport from the peripheral tissues to

\footnotetext{
Manuscript accepted for publication May 20, 2014

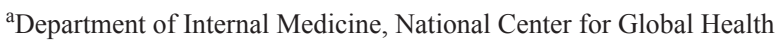
and Medicine Kohnodai Hospital, Chiba, Japan

${ }^{\mathrm{b}}$ The Jikei University School of Medicine, Tokyo, Japan

${ }^{\mathrm{c}}$ Corresponding Author: Hidekatsu Yanai, Department of Internal

Medicine, National Center for Global Health and Medicine Kohnodai

Hospital, 1-7-1 Kohnodai, Chiba 272-8516, Japan.

Email: dyanai@hospk.ncgm.go.jp
}

doi: http://dx.doi.org/10.14740/jem224w liver, promotion of macrophage cholesterol efflux, anti-inflammatory and anti-oxidative effects [1-3]. Therefore, low HDL-cholesterol (HDL-C) level is significantly associated with the development of coronary artery diseases (CADs) $[4,5]$.

Soy and isoflavones have been proposed to reduce the risk of CAD. A previous Japanese case-control study suggested that tofu (soybean curd) consumption may be protective against the risk of acute myocardial infarction in women [6]. The Japan Public Health Center-based study also revealed that high isoflavone intake was associated with reduced risk of cerebral infarction and myocardial infarction in Japanese women [7]. However, the underlying mechanisms for soy and isoflavone-induced reduction of risk of atherosclerotic diseases remain largely unknown. To understand effects of lifestyle including dietary factors on lipids metabolism, the existence of interracial differences should be considered.

Here we reviewed published articles about effect of soy and isoflavone intake on HDL metabolism. We regarded systematic review and meta-analysis and also clinical studies which were performed in Asian populations as important articles in this review.

\section{Meta-Analyses to Evaluate Effects of Soy Pro- tein and Isoflavones on HDL Metabolism}

Meta-analyses to study effects of soy protein and isoflavones on HDL-C were shown in Table 1. Taku et al conducted a meta-analysis to evaluate effects of soy isoflavones on lipid profiles [8]. The effects of soy protein that contains enriched and depleted isoflavones were also examined. Eleven studies were selected for the meta-analysis. Soy isoflavones showed no significant changes in HDL-C. Soy protein with enriched isoflavones significantly increased HDL-C by $3.0 \%$.

Reynolds et al performed a meta-analysis to examine the effect of soy protein supplementation on serum lipids in adults, by searching MEDLINE (1966 to February 2005) [9]. A total of 41 randomized controlled trials (RCTs) in which isolated soy protein supplementation was the only intervention and the net changes in serum lipids during intervention were reported. Soy protein supplementation was associated 
Table 1. Meta-Analyses to Evaluate Effects of Soy Protein and Isoflavones on High-Density Lipoprotein Cholesterol (HDL-C)

\begin{tabular}{|c|c|c|c|}
\hline Authors & Aim of study & Subjects studied & Results/conclusions \\
\hline Taku et al [8] & $\begin{array}{l}\text { The meta-analysis to } \\
\text { evaluate the precise effects } \\
\text { of soy isoflavones on lipid } \\
\text { profiles }\end{array}$ & $\begin{array}{l}\text { PubMed was searched for randomized } \\
\text { controlled trials published from } 1990 \text { to } \\
2006 \text { that described the effects of soy } \\
\text { protein intake in humans. Eleven studies } \\
\text { were selected for the meta-analysis. }\end{array}$ & $\begin{array}{l}\text { Soy isoflavones did not } \\
\text { change HDL-C, and soy } \\
\text { protein with enriched } \\
\text { isoflavones significantly } \\
\text { increased HDL-C by } 3.0 \% \text {. }\end{array}$ \\
\hline $\begin{array}{l}\text { Reynolds et } \\
\text { al [9] }\end{array}$ & $\begin{array}{l}\text { The meta-analysis to } \\
\text { examine the effect of soy } \\
\text { protein supplementation on } \\
\text { serum lipid levels in adults }\end{array}$ & $\begin{array}{l}\text { A total of } 41 \text { randomized controlled } \\
\text { trials in which isolated soy protein } \\
\text { supplementation was the only } \\
\text { intervention and the net changes in } \\
\text { serum lipids during intervention were } \\
\text { reported. }\end{array}$ & $\begin{array}{l}\text { Soy protein supplementation } \\
\text { was associated with a } \\
\text { significant increase in HDL-C } \\
(0.77 \mathrm{mg} / \mathrm{dL}, 95 \% \mathrm{CI}: 0.20 \text { - } \\
1.34) \text {. }\end{array}$ \\
\hline Zhan et al [10] & $\begin{array}{l}\text { To identify and quantify } \\
\text { the effects of soy protein } \\
\text { containing isoflavones on } \\
\text { lipid profiles }\end{array}$ & $\begin{array}{l}\text { Twenty-three eligible randomized } \\
\text { controlled trials published from } 1995 \text { to } \\
2002 \text { were identified from the PubMed } \\
\text { database. }\end{array}$ & $\begin{array}{l}\text { Soy protein with isoflavones } \\
\text { intact was associated with } \\
\text { significant increases in serum } \\
\text { HDL-C }(3.03 \%) \text {. }\end{array}$ \\
\hline $\begin{array}{l}\text { Weggemans et } \\
\text { al [11] }\end{array}$ & $\begin{array}{l}\text { To study specifically the } \\
\text { effect of soy-associated } \\
\text { isoflavones on cholesterol } \\
\text { concentrations in well- } \\
\text { controlled trials substituting } \\
\text { soy protein with dairy or } \\
\text { animal protein }\end{array}$ & $\begin{array}{l}\text { Studies comprised } 959 \text { subjects ( } 336 \\
\text { men and } 623 \text { women), average age } \\
\text { ranged from } 41 \text { to } 67 \text { years old and } \\
\text { baseline cholesterol concentration ranged } \\
\text { from } 5.42 \text { to } 6.60 \mathrm{mmol} / \mathrm{L} \text {. }\end{array}$ & $\begin{array}{l}\text { Feeding daily } 36 \mathrm{~g} \text { soy protein } \\
\text { with } 52 \mathrm{mg} \text { soy-associated } \\
\text { isoflavones on average } \\
\text { increased HDL-C by } 0.03 \pm \\
0.01 \mathrm{mmol} / \mathrm{L} \text {. }\end{array}$ \\
\hline
\end{tabular}

with a significant increase in HDL-C $(0.77 \mathrm{mg} / \mathrm{dL}, 95 \%$ CI: 0.20 - 1.34), and the meta-regression analyses showed a dose-response relation between intake of soy protein and isoflavone supplementation and net changes in serum lipids.

Zhan et al conducted a meta-analysis to identify and quantify the effects of soy protein containing isoflavones on serum lipids [10]. Twenty-three eligible RCTs published from 1995 to 2002 were identified from the PubMed database. Soy protein with isoflavones intact was associated with significant increases in serum HDL-C by $0.04 \mathrm{mmol} / \mathrm{L}$ $(3.03 \%)$. Initial total cholesterol concentrations had a powerful effect on changes in HDL-C. Studies with intakes $>80$ mg showed better effects on serum lipids. Improvements in HDL-C were only observed in studies of $>12$ weeks duration.

Weggemans et al performed a meta-analysis to study specifically the effect of soy-associated isoflavones on cholesterol concentrations in well-controlled trials substituting soy protein with dairy or animal protein by MEDLINE searches (1995 - 2002) [11]. Studies comprised 959 subjects
(336 men and 623 women), average age ranged from 41 to 67 years and baseline cholesterol concentration ranged from 5.42 to $6.60 \mathrm{mmol} / \mathrm{L}$. Feeding daily $36 \mathrm{~g}$ soy protein with 52 $\mathrm{mg}$ soy-associated isoflavones on average increased HDL-C by $0.03 \pm 0.01 \mathrm{mmol} / \mathrm{L}$. There was no dose-response relation between soy-associated isoflavones and HDL-C (correlation coefficient: $-0.07 ; \mathrm{P}=0.76$ ).

Evidences obtained from meta-analyses showed that intake of soy protein and isoflavones is beneficially associated with HDL metabolism.

\section{Clinical Trials to Study Effects of Soy Protein and Isoflavones on HDL Metabolism in Asian Populations}

Clinical trials to study effects of soy protein and isoflavones on HDL-C in Asian populations were shown in Table 2. Liu et al studied the effects of moderate intake of soy protein (15 g) with isoflavones or isoflavones alone on serum lipids in 


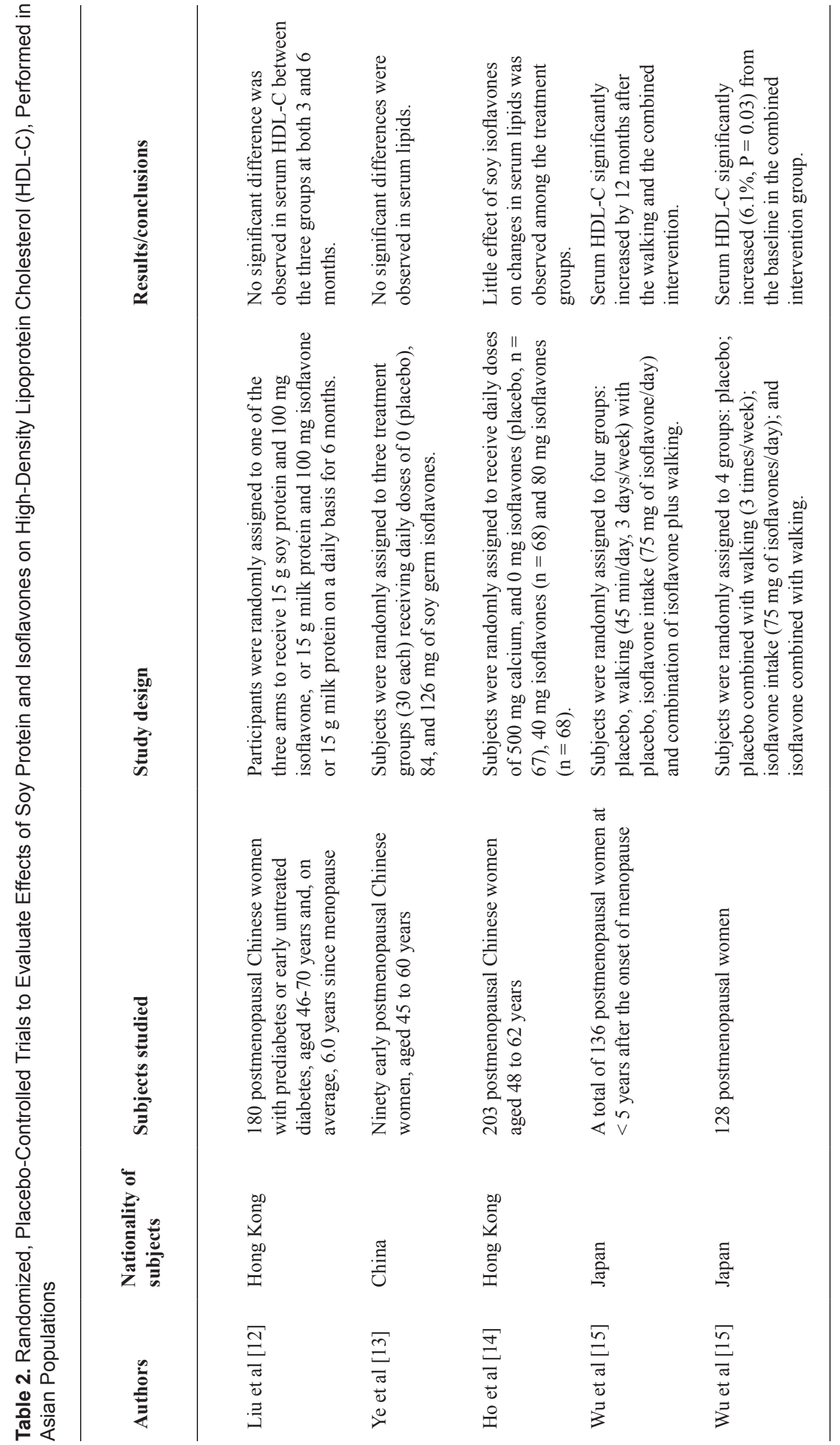


180 Chinese postmenopausal, prediabetic women, aged 4670 years and, on average, 6.0 years since menopause [12]. Participants were randomly assigned to one of the three arms to receive $15 \mathrm{~g}$ soy protein and $100 \mathrm{mg}$ isoflavone, or $15 \mathrm{~g}$ milk protein and $100 \mathrm{mg}$ isoflavone or $15 \mathrm{~g}$ milk protein on a daily basis for 6 months. The results showed that no significant difference was observed in serum HDL-C between the three groups at both 3 and 6 months.

Ye et al examined the effect of soy germ isoflavones on serum lipids [13]. Ninety early postmenopausal Chinese women, aged 45 to 60 years, were randomly assigned to three treatment groups (30 each) receiving daily doses of 0 (placebo), 84 and $126 \mathrm{mg}$ of soy germ isoflavones. No significant differences were observed in serum lipids.

Ho et al examined the effects of isolated soy germ isoflavones on the changes in serum lipids [14]. RCT was conducted in 203 postmenopausal Chinese women aged 48 to 62 years. They were randomly assigned to receive daily doses of $500 \mathrm{mg}$ calcium, and $0 \mathrm{mg}$ isoflavones (placebo, $\mathrm{n}=67$ ), $40 \mathrm{mg}$ isoflavones $(\mathrm{n}=68)$ and $80 \mathrm{mg}$ isoflavones $(\mathrm{n}=68)$. They observed little effect of soy isoflavones on changes in serum lipids among the treatment groups.

$\mathrm{Wu}$ et al studied the effects of isoflavone intake, walking exercise and their interaction on lipid metabolism over 1 year in postmenopausal Japanese women [15]. A total of 136 postmenopausal women at $<5$ years after the onset of menopause were randomly assigned to four groups: placebo, walking (45 min/day, 3 days/week) with placebo, isoflavone intake ( $75 \mathrm{mg}$ of isoflavone conjugates/day), and combination of isoflavone plus walking. Serum HDL-C significantly increased by 12 months after the walking and the combined intervention.

$\mathrm{Wu}$ et al also performed one more study to evaluate effects of isoflavone intake and walking and their interaction on serum lipid metabolism in postmenopausal women over 24 weeks [16]. One hundred twenty-eight subjects were randomly assigned to four groups: placebo; placebo combined with walking (3 times/week); isoflavone intake (75 mg of isoflavones conjugates/day); and isoflavone combined with walking. Serum HDL-C significantly increased $(6.1 \%, \mathrm{P}=$ 0.03 ) from the baseline in the combined intervention group.

Three RCTs showed that soy and isoflavone intake is not associated with increases in HDL-C in postmenopausal women. Two RCTs showed significant increases in HDL-C due to soy and isoflavone intake in postmenopausal women; however, these increases were only observed by combination with walking.

\section{Conclusions}

Evidences obtained from RCTs performed in Asian populations showed that effects of soy protein and isoflavones on HDL-C were limited, which is may be due to limited studied population such as postmenopausal women. Meta-analyses indicated that intake of soy protein and isoflavones is beneficially associated with HDL metabolism.

\section{Acknowledgement}

This work was supported by a grant from the National Center for Global Health and Medicine (25-203).

\section{Conflict of Interests}

The authors declare that they have no competing interests.

\section{Funding}

This work was funded by a grant from the National Center for Global Health and Medicine (25-203).

\section{References}

1. Eren E, Yilmaz N, Aydin O. High Density Lipoprotein and it's Dysfunction. Open Biochem J. 2012;6:78-93.

2. Annema W, Tietge UJ. Role of hepatic lipase and endothelial lipase in high-density lipoprotein-mediated reverse cholesterol transport. Curr Atheroscler Rep. 2011;13(3):257-265.

3. deGoma EM, deGoma RL, Rader DJ. Beyond high-density lipoprotein cholesterol levels evaluating high-density lipoprotein function as influenced by novel therapeutic approaches. J Am Coll Cardiol. 2008;51(23):2199-2211.

4. Kitamura A, Iso H, Naito Y, Iida M, Konishi M, Folsom AR, Sato S, et al. High-density lipoprotein cholesterol and premature coronary heart disease in urban Japanese men. Circulation. 1994;89(6):2533-2539.

5. Yokokawa H, Yasumura S, Tanno K, Ohsawa M, Onoda T, Itai K, Sakata K, et al. Serum low-density lipoprotein to high-density lipoprotein ratio as a predictor of future acute myocardial infarction among men in a 2.7-year cohort study of a Japanese northern rural population. J Atheroscler Thromb. 2011;18(2):89-98.

6. Sasazuki S, Fukuoka Heart Study G. Case-control study of nonfatal myocardial infarction in relation to selected foods in Japanese men and women. Jpn Circ J. 2001;65(3):200-206.

7. Kokubo Y, Iso H, Ishihara J, Okada K, Inoue M, Tsugane S, Group JS. Association of dietary intake of soy, beans, and isoflavones with risk of cerebral and myocardial infarctions in Japanese populations: the Japan Public Health Center-based (JPHC) study cohort I. Circulation. 
2007;116(22):2553-2562.

8. Taku K, Umegaki K, Sato Y, Taki Y, Endoh K, Watanabe S. Soy isoflavones lower serum total and LDL cholesterol in humans: a meta-analysis of 11 randomized controlled trials. Am J Clin Nutr. 2007;85(4):1148-1156.

9. Reynolds K, Chin A, Lees KA, Nguyen A, Bujnowski D, He J. A meta-analysis of the effect of soy protein supplementation on serum lipids. Am J Cardiol. 2006;98(5):633-640.

10. Zhan S, Ho SC. Meta-analysis of the effects of soy protein containing isoflavones on the lipid profile. Am J Clin Nutr. 2005;81(2):397-408.

11. Weggemans RM, Trautwein EA. Relation between soyassociated isoflavones and LDL and HDL cholesterol concentrations in humans: a meta-analysis. Eur J Clin Nutr. 2003;57(8):940-946.

12. Liu ZM, Ho SC, Chen YM, Ho YP. The effects of isoflavones combined with soy protein on lipid profiles, C-reactive protein and cardiovascular risk among postmenopausal Chinese women. Nutr Metab Cardiovasc Dis. 2012;22(9):712-719.
13. Ye YB, Wang ZL, Zhuo SY, Lu W, Liao HF, Verbruggen $\mathrm{M}$, Fang S, et al. Soy germ isoflavones improve menopausal symptoms but have no effect on blood lipids in early postmenopausal Chinese women: a randomized placebo-controlled trial. Menopause. 2012;19(7):791798.

14. Ho SC, Chen YM, Ho SS, Woo JL. Soy isoflavone supplementation and fasting serum glucose and lipid profile among postmenopausal Chinese women: a doubleblind, randomized, placebo-controlled trial. Menopause. 2007;14(5):905-912.

15. Wu J, Oka J, Tabata I, Higuchi M, Toda T, Fuku N, Ezaki $\mathrm{J}$, et al. Effects of isoflavone and exercise on BMD and fat mass in postmenopausal Japanese women: a 1-year randomized placebo-controlled trial. J Bone Miner Res. 2006;21(5):780-789.

16. Wu J, Oka J, Higuchi M, Tabata I, Toda T, Fujioka M, Fuku N, et al. Cooperative effects of isoflavones and exercise on bone and lipid metabolism in postmenopausal Japanese women: a randomized placebo-controlled trial. Metabolism. 2006;55(4):423-433. 